\title{
Effect of Ajinomoto (MSG) on Weight \& Length of Uterine Tubes of Female Albino Rats
}

${ }^{1}$ Sobia Ibrahim, ${ }^{1}$ Shazia Tufail, ${ }^{2}$ Muhammad Suhail

${ }^{1}$ Department of Anatomy, King Edward Medical University, Lahore

${ }^{2}$ Department of Anatomy, Saikh Zayed Medical Complex, Lahore

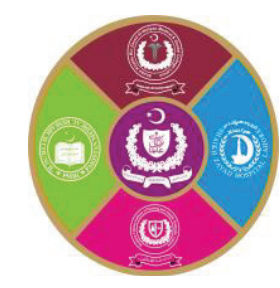

\section{ABSTRACT}

Introduction: Ajinomoto (MSG) is the most popular and frequently used food additive. It is used to enhance the taste of food and is also used for preservation of food. Its use has been there for a longer period of time \& has now become an essential component of almost all prepared salty food items. This extensively used product has various health concerns so this study has been conducted. Aims \& Objectives: To see the effects of ajinomoto (MSG) given to the female albino rats on weight and length of uterine tubes. Place and duration of study: This experimental study of 2 weeks duration was conducted in the Department of Anatomy, Shaikh Zayed Postgraduate Medical Institute, Lahore. Material \& Methods: 45 female rats were divided into three equal groups in a random fashion i.e. one control group A, other two experimental groups B $\&$ C. Salt (ajinomoto-MSG) was given in a dose of $0.04 \mathrm{mg} / \mathrm{kg}$ body weight to animals of group B i.e. low dose group and $0.08 \mathrm{mg} / \mathrm{kg}$ body weight to group C i.e. high dose group for about two weeks after dissolution in $1 \mathrm{ml}$ of distilled water. Animals of Group A i.e. control group were given only equal amount of distilled water without any salt for same days. They were sacrificed on fifteenth day of the experiment. The uterine tubes were approached and carefully dissected out of abdomen. Gross examination was done for any apparent abnormality. Tubes were then weighed and their lengths were taken. Tissue fixation was done \& serial 3-5 $\mu \mathrm{m}$ thick sections were stained with hematoxylin/eosin stains for their detailed histological study. Results: Uterine tubes of both low dose and high dose experimental groups showed reduced weight and length as compared to tubes of animals of control group. Conclusion: Ajinomoto (MSG) causes decrease in weight and length of uterine tubes.

Key words: Monosodium Glutamate (MSG), albino rat, uterine tubes.

\section{INTRODUCTION}

A jinomoto (MSG) is the most commonly used flavor enhancer. East-Asians were using it as a seaweed broth in their cooking for a long time. It was adding meaty taste to their meals. For these reasons it was very popular among them but its proper discovery was made by a Professor of Tokyo University Kikunae Ikeda. He found it as brown colored crystals left after the evaporation of an aqueous solution of this seaweed extract. These crystal were called as "umami" by him in $1907 .{ }^{1}$ Later on a method was launched by scientists for large scale production of MSG under Ajinomoto Corporation in Japan. ${ }^{2}$ Hence it got the name of Ajinomoto.

Its major component- glutamic acid is present naturally in protein rich foods such as nuts, legumes, mushrooms, meat, tomatoes, and many dairy products. ${ }^{3}$ Mostly it is bound with other amino acids but small amount of it is found as free form enhancing the flavor of food. It is the high content of free glutamate in food which is basically adding or enhancing taste. ${ }^{4}$ Synthetically it was at first produced by fermentation of wheat gluten and then by fermentation of nitrogenous carbohydrates using bacteria. $^{5,6}$ Nowadays its production is done on large scale by the fermentation of nitrogenous carbohydrates with genetically treated bacteria. ${ }^{6,7}$ Initially its use was limited to east- Asians only but later on it gets popularity throughout the world because of flavor enhancing capability. Along with its wide \& extensive use multiple questions were being raised from time to time for its safe use. Various health concerns came forward from time to time but despite all, it remained as the most favorite flavor enhancing agent throughout the world. ${ }^{8}$ Its first side effect was observed by scientists in 1957 during conduction of an animal study on retina, ${ }^{9}$ but got unnoticed. The most eye-opening side effects were reported in 1968 by the New England Journal of Medicine as cascade of symptoms including 
nausea, vomiting, headache, chest tightness, tingling, facial swellings, increased heart rate etc ${ }^{10}$ collectively labeled as "Chinese restaurant syndrome". This observation directed all researchers and scientists of world to analyze it for its other effects. Multiple researches were carried out on various experimental animals and different organs of the body and it was proved as retinotoxic, ${ }^{11}$ neurotoxic, ${ }^{12}$ nephrotoxic, ${ }^{13}$ hepatotoxic ${ }^{14}$ etc. Research work on male reproductive organs also established it as a substance implicating in male infertility by causing testicular hemorrhage and oligoozospermia. ${ }^{15}$ In female reproductive organs it was found to produce cystic degeneration \& atretic follicles in ovaries and also uterine fibroids by interfering with estrogen levels. ${ }^{16}$ Present study was thus conducted to rule out its various morphological and histological effects on uterine tubes of female albino rats.

\section{MATERIAL AND METHODS}

This study was conducted in the Department of Anatomy, Shaikh Zayed Postgraduate Medical Institute, Lahore.

$\begin{array}{ll}\text { Study Design: } & \text { Experimental Study } \\ \text { Study duration: } & 2 \text { weeks }\end{array}$

45 female albino rats were purchased for this study. They were acclimatized for about a week by keeping in animal house of Punjab Post Graduate Medical Institute, Lahore. Feed ${ }^{17}$ was provided to them and free access to food and water was confirmed. Their 12 hours light/dark cycles were maintained \& then after two weeks animals were assigned into control (A) \& experimental groups (B and $\mathrm{C}$ ) in a random fashion.

\section{Group A (Control):}

Control group consisted of 15 rats that received equal amount of distilled water along with MSG free normal chick feed for 14 days.

\section{Group B (Experimental):}

Low dose experimental group comprised of 15 rats that were given MSG $0.04 \mathrm{mg} / \mathrm{kg} /$ day once a day for 14 days after dissolving in $1 \mathrm{ml}$ of distilled water through orogastric tube.

\section{Group C (Experimental):}

High dose experimental group comprised of 15 rats that were given $0.08 \mathrm{mg} / \mathrm{kg} /$ day of MSG once a day for 14 days after dissolving in $1 \mathrm{ml}$ of distilled water through orogastric tube.

Dissection was made on the fifteenth day of the experiment. Morphine was used for analgesia and sodium pentabarbitone for anesthesia. ${ }^{18}$ Rats were fixed one by one in supine position on dissection board. Abdominal cavities were opened by anterior abdominal wall incision. Intestines were taken out \& uterine tubes were identified (Fig-1). Bilateral uterine tubes were dissected out keeping ovaries and uterus intact. Their gross inspection was done \& were later on weighed on electronic weighing machine. Lengths were taken after straightening them with the help of a steel ruler. These tubes were then fixed in formaldehyde for 24-36 hours \& their embedded paraffin blocks were prepared after dehydration. ${ }^{19}$ Glass slides of 3-5 $\mu \mathrm{m}$ thick sections were prepared \& stained with Haematoxylin and Eosin (H\&E) method ${ }^{20}$ for histological examination.

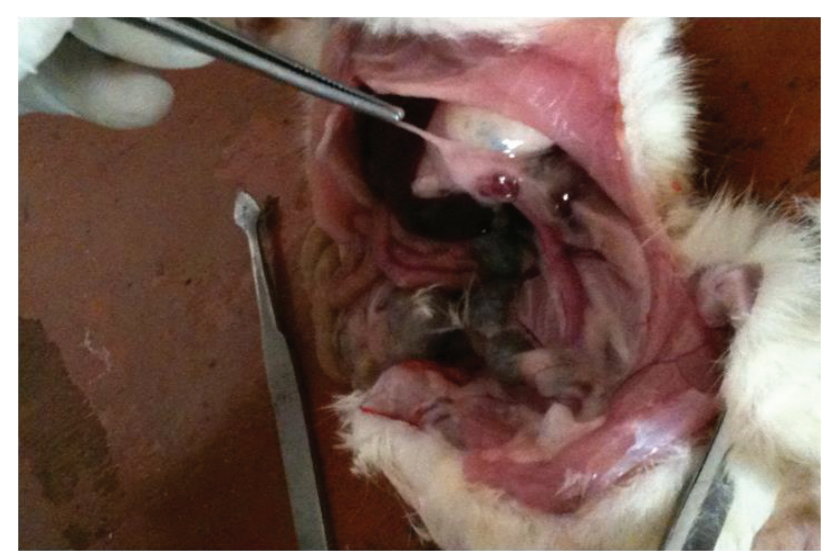

Fig-1: Uterine tubes of albino rat attached to ovaries

\section{Statistical analysis:}

All observations were entered in computer and SPSS version 21.0 was applied for analysis. Both types of variables (qualitative \& quantitative) were compared using Chi-square test \& ANOVA.

\section{RESULTS}

After sacrifice, when uterine tubes were dissected out carefully and weighed, it was noted that animals of the control group had highest weight of tubes which was $43.07 \pm 10.89 \mathrm{mg}$, while in low dose experimental group B it was recorded $33.67 \pm 6.87$ $\mathrm{mg}$ and in high dose experimental group $\mathrm{C}$ it was $28.80 \pm 12.34 \mathrm{mg}$ (Table-1). There was statistically significant variation in weight of uterine tubes in the three groups (Table-2).

\begin{tabular}{|l|l|l|l|l|}
\hline Groups & $\begin{array}{l}\text { Mean } \\
\text { weight (mg) }\end{array}$ & $\begin{array}{l}\text { Standard } \\
\text { Deviation }\end{array}$ & $\begin{array}{l}\text { Min. } \\
\text { weight }\end{array}$ & $\begin{array}{l}\text { Max. } \\
\text { weight }\end{array}$ \\
\hline $\begin{array}{l}\text { Group A } \\
\text { (Control) }\end{array}$ & 43.07 & 10.89 & 27 & 57.0 \\
\hline $\begin{array}{l}\text { Group B } \\
\text { (Low-dose } \\
\text { experimental) }\end{array}$ & 33.67 & 6.87 & 24.0 & 45.0 \\
\hline $\begin{array}{l}\text { Group C } \\
\text { (High-dose } \\
\text { experimental) }\end{array}$ & 28.80 & 12.34 & 14.0 & 54.0 \\
\hline
\end{tabular}

Table-1: Mean weight of Uterine tubes of female albino rats 


\begin{tabular}{|c|c|c|c|c|c|}
\hline & $\begin{array}{c}\text { Sum of } \\
\text { squares }\end{array}$ & $\begin{array}{c}\text { Degree of } \\
\text { Freedom }\end{array}$ & $\begin{array}{c}\text { Mean } \\
\text { squares }\end{array}$ & $\begin{array}{c}\text { Ratio of } \\
\text { Variance }\end{array}$ & P-value \\
\hline $\begin{array}{c}\text { Inter } \\
\text { Groups }\end{array}$ & 1577.91 & 2 & 788.95 & 7.44 & $0.002 * *$ \\
\hline $\begin{array}{c}\text { Intra } \\
\text { Groups }\end{array}$ & 4452.66 & 42 & 106.02 & & \\
\hline Total & 6030.57 & 44 & & & \\
\hline
\end{tabular}

Table-2: Various group comparisons for mean weight (mg) of uterine tubes of female albino rats.

\section{Based on ANOVA}

** Highly significant difference $(\mathrm{p}<0.01)$

When weight of uterine tubes was compared group wise it showed that tubes of low dose \& high dose experimental groups $\mathrm{B}$ and $\mathrm{C}$ had significantly more weight as compared to control group A but the difference in weight of both of experimental groups $\mathrm{B}$ and $\mathrm{C}$ was insignificant (Table-3, Fig-2).

\begin{tabular}{|c|c|c|c|c|}
\hline Groups & Groups & $\begin{array}{c}\text { Mean } \\
\text { Difference }\end{array}$ & $\begin{array}{c}\text { Std. } \\
\text { error }\end{array}$ & P-value \\
\hline $\begin{array}{c}\text { Control } \\
\text { Group A }\end{array}$ & Group B & $9.40^{*}$ & 3.76 & $0.042^{*}$ \\
\cline { 2 - 5 } & Group C & $14.27^{*}$ & 3.76 & $0.001^{* *}$ \\
\hline $\begin{array}{c}\text { Experimental } \\
\text { (low-dose) } \\
\text { Group B }\end{array}$ & Group C & 4.87 & 3.76 & $0.406^{++}$ \\
\hline
\end{tabular}

Table-3: Group wise comparison for weight of uterine tubes (mg) of female albino rats.

*The mean difference is significant at the .05 level.

\section{Based on TUKEY'S Test}

** Highly significant difference $(\mathrm{p}<0.01)$

$+\quad$ Insignificant difference $(\mathrm{p}>0.05)$

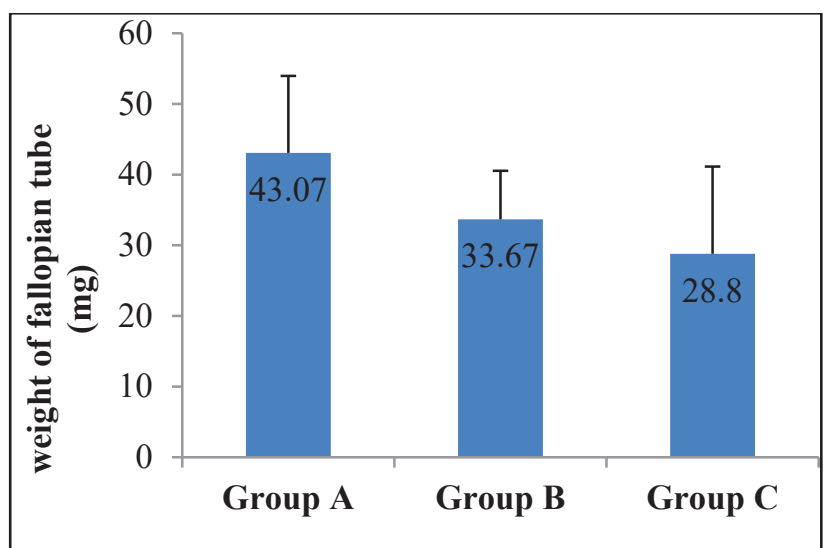

Fig-2: Graph showing comparison of mean uterine tube weight of female albino rats-control \& both low \& high dose experimental groups.

Similarly when length of uterine tubes was measured using steel ruler from ovarian to uterine ends after dissecting out, the animals of control group had maximum length of uterine tubes
$2.28 \pm 0.35 \mathrm{~cm}$, while in low dose experimental group B it was recorded $1.90 \pm 0.42 \mathrm{~cm}$ and $1.84 \pm 0.39$ in high dose experimental group $\mathrm{C}$ (Table-4). The difference in length of tubes between these groups was significant (Table-5).

\begin{tabular}{|c|c|c|c|c|}
\hline Groups & $\begin{array}{c}\text { Mean } \\
\text { lengths -cm }\end{array}$ & $\begin{array}{c}\text { Standard } \\
\text { Deviation }\end{array}$ & $\begin{array}{c}\text { Min. } \\
\text { length }\end{array}$ & $\begin{array}{c}\text { Max. } \\
\text { length }\end{array}$ \\
\hline $\begin{array}{c}\text { Control } \\
\text { Group A }\end{array}$ & 2.28 & 0.35 & 1.55 & 2.85 \\
\hline $\begin{array}{c}\text { Experimental } \\
\text { Group B } \\
\text { (low dose) }\end{array}$ & 1.90 & 0.42 & 1.15 & 2.85 \\
\hline $\begin{array}{c}\text { Experimental } \\
\text { Group C } \\
\text { (high dose) }\end{array}$ & 1.84 & 0.39 & 1.15 & 2.65 \\
\hline
\end{tabular}

Table-4: Mean length (cm) of uterine tubes of female albino rats

\begin{tabular}{|c|c|c|c|c|c|}
\hline & $\begin{array}{c}\text { Sum of } \\
\text { squares }\end{array}$ & $\begin{array}{c}\text { Degree of } \\
\text { Freedom }\end{array}$ & $\begin{array}{c}\text { Mean } \\
\text { squares }\end{array}$ & $\begin{array}{c}\text { Ratio of } \\
\text { variance }\end{array}$ & P-value \\
\hline $\begin{array}{c}\text { Inter } \\
\text { Groups }\end{array}$ & 1.708 & 2 & 0.854 & 5.693 & $0.006^{* *}$ \\
\hline $\begin{array}{c}\text { Intra } \\
\text { Groups }\end{array}$ & 6.300 & 42 & 0.150 & & \\
\hline Total & 8.008 & 44 & & & \\
\hline
\end{tabular}

Table-5: Various group comparison for lengths of uterine tubes

\section{Based on ANOVA}

** Highly significant difference $(\mathrm{p}<0.01)$

When individual group comparison for mean length of uterine tubes of albino rats was done, results showed that both experimental groups (low \&high dose) $\mathrm{B}$ and $\mathrm{C}$ had significantly short length of tubes as compared to animals of control group A. However the difference of length between both experimental groups i.e. $\mathrm{B}$ and $\mathrm{C}$ was insignificant (Table-6, Fig-3).

\begin{tabular}{|c|c|c|c|c|}
\hline Groups & Groups & $\begin{array}{c}\text { Mean } \\
\text { Difference }\end{array}$ & Std. error & P-value \\
\hline \multirow{2}{*}{ Group A } & Group B & $0.38(*)$ & 0.14 & $0.027^{* *}$ \\
\cline { 2 - 5 } & Group C & $0.44(*)$ & 0.14 & $0.009 * *$ \\
\hline Group B & Group C & 0.06 & 0.14 & $0.906^{++}$ \\
\hline
\end{tabular}

Table-6: Various groups comparison for mean length $(\mathrm{cm})$ of uterine tubes of female albino rats

* The mean difference is significant at the .05 level.

Based on TUKEY'S Test

** Highly significant difference $(\mathrm{p}<0.01)$

+ Insignificant difference $(\mathrm{p}>0.05)$ 


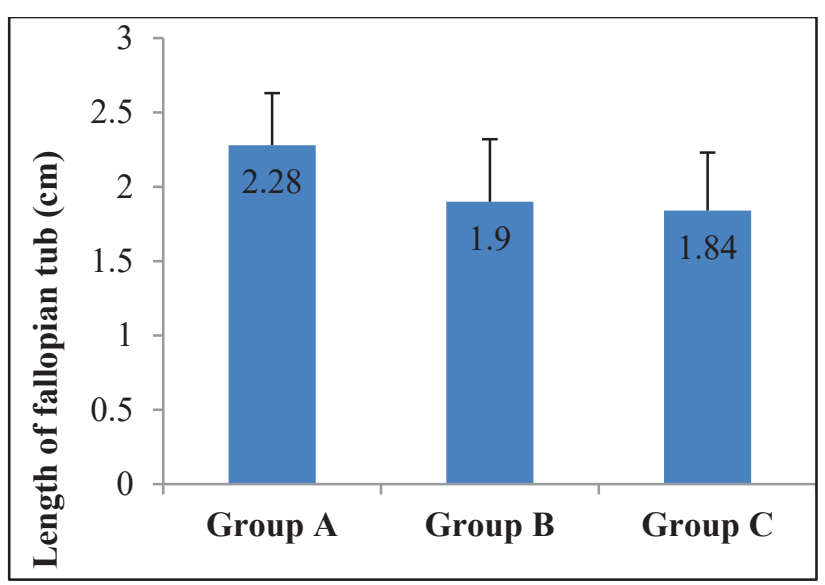

Fig-3: Graph showing comparison of mean length of uterine tubes of female albino rats-control \& experimental groups

\section{DISCUSSION}

The use of synthetic salt is getting popular in our society. This improves the flavor and makes the food tasty and easily palatable. Ajinomoto is one of the most commonly used such salt; previously associated with Chinese food only but now is a choice of every food company for its products. It is also naturally present in our food as proteins. Although it is in extensive usage but still questions are there for its safe use. Research work is being continuously carried on to observe its effects on various organs..$^{21}$ Present study was also planned to see any effects on morphology and histology of uterine tubes.

When weight of organ was recorded it was noticed that weight of uterine tubes in experimental groups both low \& high dose B and C were significantly less than that of control group A with p-values 0.042 and 0.001 respectively (Table- 3 ). This observation of weight reduction of uterine tubes is identical with weight loss of testis in an animal study conducted by Nayantara et al. in 2008. The study was performed on rats to see the effects of ascorbic acid on MSG induced changes in testis \& it was observed that there was a loss of testicular weight in animals who received MSG on both short term and long term basis. ${ }^{22}$ In the present study length of uterine tubes were also taken after dissection and it was observed that the tubes of both experimental (low \& high dose) groups B and C were of shorter length as compared to that of control group A with p-value 0.027 and 0.009 (Table-6).

MSG is known to cause reactive oxidative damage by the release of free radicals \& both results of the present study i.e. reduction in weight and length of organ could be due to reactive oxidative damage created by free radical release by MSG. It is known that a cell responds to any inner or outer insult by different responses which include permeability change in membrane, ATP depletion, mitochondrial loss, calcium ions influx or intra cellular accumulation of oxygen derived free radicals. These responses vary according to severity and duration of insulting factors $\&$ progress to degeneration. ${ }^{23}$ In the present study there could be increased oxidative stress because of release of free radicals leading to irreversible cell injury. This is a possible explanation for the results of present study pertaining to reduction in weight and length of uterine tubes in both low and high dose experimental groups.

\section{CONCLUSION}

The results of the present research work indicate that oral administration of ajinomoto for two weeks caused reduction in weight and length of fallopian tubes.

However if this is given in food for a longer period of time it could cause severe effects on major organs and could be a cause of female infertility.

\section{REFERENCES}

1. C. Sarah The discovery of umami: How MSG changes the culinary world: JT: 2017, Jan. 20 Friday.

2. Kikunae Ikeda Sodium Glutamate. Prepared by Japan Patent Office. 2002; Oct. 7[online] Available at:

http://www.jpo.go.jp/seido e/rekishi e/kikunae ikeda.html

3. RD, Shafer Jeissi A brief-and interesting-history of MSG: deliciousliving: 2016, Sept, 30. Available at :

https://www.deliciousliving.com/health/nutritio $\mathrm{n} / \mathrm{brief}$-and-interesting-history-msg/

4. Monosodium Glutamate OR Ajinomoto Eatoutzone Available at www.eatoutzone.html

5. K.Zehra, F. Iffat, P. Shugufta et al, Monosodium glutamate: Review on clinical reports: IJFP: 2017, Feb. 22, 20(2):1807-1815.

6. http://en.wikipedia.org/wiki/Monosodium gluta $\underline{\text { mate }}$

7. http://en.wikipedia.org/wiki/Umami

8. Jong Sde. Review on Monosodium Glutamates.FOOD-INFO. 2003; Wageningen university.

9. Samuels Anderinne. Retinal degeneration: This is what the data say about Monosodium Glutamate Toxicity and the Central Nervous System. 2009. 
10. Bodeeb J. Bad Effects of Monosodium Glutamate. Live strong Foundation. 2010; Dec.6

11. Retinal Degeneration: Early Evidence of MSG Toxicity. New Research Findings Two. Wednesday, April 20, 2011.

12. Ikonomidou C, Turski L. Neurodegenerative disorders: clues from glutamate and energy metabolism.

13. S. Amood Monosodium glutamate-induced oxidative kidney damage and possible mechanisms: a mini-review. J Biomed Sci. $2015 ; 22: 93$

14. E. Mohamad, A. Eladl Mohamad, El. S Mohamad et al, Hepatotoxicity of Monoglutamate Sodium: Oxidative Stress and Histopathlogical Study: TFASEBJ: 2017, April $1 ; 31(1)$.

15. Oforofuo IAO, Onakewhor JUE, Idaewor PE. The effect of Chronic Administration of MSG on the histology of Adult Wistar rat Testes. Bioscience Research Communications. 1997,6;9(2):30-56

16. Obochi GO, Malu SP, Obi-Abang M, Alozie Y, Iyam MA. Effects of Garlic Extract on Monosodium Glutamate (MSG) Induced Fibroid in Wistar Rats. Pak J. of Nutrition. 2009; 8(7): 970-76

17. Preston RL. Feed Composition Tables [Internet]. 2006 [updated 2007 Feb 12; cited 2010 Dec 17]. Available from: http://www.beefmagazine.com $/ \mathrm{mag} /$ beef feed composition tables 2

18. AVMA guidelines on Euthenazia.

19. Bancroft JD, Gamble M. Theory and practice of histological techniques. 5th ed. London: Churchill Livingstone; 2002. p.75.
20. Drury RAB, Wallington EA. Carleton's Histological Technique. 5th ed. UK: Oxford University Press; 2007. p. 235-7.

21. Minton BL. The Dangers of MSG. Natural News[Online] Available at: htp://www.naturalnews.com/025353 MSG food brain.html

22. Nayanatara AK, Vinodini NA, Damodar G, Ahmed B, Ramaswamy CR, Shabarianth et al. Role of ascorbic acid in monosodium glutamate mediated effect on testicular weight, sperm morphology and sperm count, in rat testis. 2008.

23. Klaassen, C.D, Ed.: Casarett and Doull's Toxicology: The Basic Science of Poisons. 6th Edition, Mc Graw-Hill 2007 [2001].

\section{The Authors:}

Dr. Sobia Ibrahim,

Assisstant Professor,

Department of Anatomy,

King Edward Medical University, Lahore.

Dr. Shazia Tufail,

Assistant Professor

Department of Anatomy,

King Edward Medical University, Lahore

Prof. Muhammad Suhail,

Head of Anatomy Department,

FPGMI, Shaikh Zayed Medical Complex, Lahore.

\section{Corresponding Author:}

Dr. Sobia Ibrahim

Assistant Professor Anatomy,

KEMU, Lahore

E-mail:drsobiaibrahim@gmail.com 